\title{
Visible Light Promoted One-Pot, Three Component Reaction for the Synthesis of quinazolines
}

\author{
Parshuram MP1 ${ }^{1}$, Vinod TK², Ravi V3* and Pradip BG ${ }^{4}$ \\ ${ }^{1}$ School of Chemical Science, Swami Ramanand Teerth Marathwada University, Nanded, Maharshtra, India \\ ${ }^{2}$ Organic Chemistry Research Laboratory, Department of Chemistry, Institute of Science, Nagapur, Maharashtra, India \\ ${ }^{3}$ Scrips Pharma, Mallapur, Hyderabad, Telangana, India \\ ${ }^{4}$ Department of Chemistry, Shri Shivaji Collage Kandhar, Swami Ramanand Teerth Marathwada University, Nanded, Maharashtra, India
}

\begin{abstract}
Highly efficient one-pot three component approach was developed for the synthesis of biological active quinazoline derivatives. By the application of visible light via $\mathrm{SP}^{3}$ $\mathrm{C}-\mathrm{H}$ bond activation, desired products were obtained in high yields. The advantages of this method are application of green chemistry approach, avoidance of toxic organic solvents, easily available starting material, simple operation and shorter reaction times.
\end{abstract}

Keywords: Visible light • Quinazolines • Solvent-free $•$ Photo catalysis

\section{Introduction}

The $\mathrm{C}-\mathrm{H}$ bonds are abundant in organic compounds, but they do not seem to be operative functional groups owing to the low relativities and high thermodynamic stabilities [1,2]. Therefore, the development a mild and effective organic transformation with clean and renewable energy is of high interest. Solar energy is a unique and renewable resource in nature [3]. Recently, application of visible light in organic transformation was reported by several prominent groups 3 for the formation of new chemical bonds $(C-C$ and $\mathrm{C}-\mathrm{X}$ ). In the past five years, owing to its significant advances in energysaving and environmentally benign features, visible-light photo redox catalysis has witnessed rapid development and attracted considerable attention in both academia and industry [4]. Quinazoline moiety plays a vital role in pharmacological and medicinal chemistry, which is the building block for several naturally occurring alkaloids [5-9]. Microorganisms [10-15], It shows other remarkable biological activity such as anti-diabetic [16], antihypertensive [17], anticancer [18], antitumor [19], antitubercular [20,21], antibacterial [22], anti-inflammatory [23], antiviral [24], and it also act as selective inhibitors of the tyrosine kinase activity of the epidermal growth factor receptor (EGFR) [25], 3, 4-dihydroquinazoline derivatives shows the excellent T-type calcium channel blocking activity [26,27], it also use as ligand for benzodiazepine and neurotransmitter gamma-aminobutyric acid [GABA] receptors in the central nervous system [CNS] [28], DNA binders $[29,30]$. In the literature, different methodologies are reported for the synthesis of quinazolines under different reaction condition and reagents, such as $\mathrm{Bu}_{3} \mathrm{SnH}$ [31], microwave [32], $\mathrm{CsOH}$ [33], $\mathrm{Zn}(\mathrm{OTf})_{2}$ [34], Microwave$\mathrm{NaOH}$ [35], $\mathrm{NH}_{4} \mathrm{OAc}-\mathrm{H}_{2} \mathrm{O}$ [36], 12 [37]. However many reported methods suffer from drawback such as drastic reaction condition, high temperature, volatile organic solvents, toxic reagents, use of expensive metal catalysts, and long reaction time. All such types of drawbacks prompt researchers to develop alternate route for the synthesis of quinazolines.

\section{The present method}

In the present method, quinazoline derivatives have been synthesized using visible light from the reaction of 2- aminobenzophenone, aldehyde and ammonium acetate under catalyst-free and solvent-free conditions. Respective was shown in Figure 1.<smiles>[R][PH2+]C(=O)c1cc[R1]cc1N</smiles>

1<smiles>CC(=O)ON[14c]1cccc(C=O)c1</smiles>

2

3

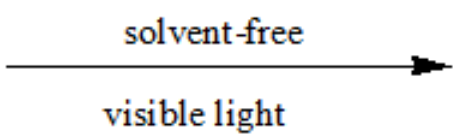<smiles>[R2]c1[R4]c2nc(-c3ccccc3)nc(-c3ccccc3)c2cc1</smiles>

$4 a-q$

Figure 1. Synthesis of quinazoline derivatives.

$\mathrm{R}_{1}=\mathrm{Cl}, \mathrm{OH}, \mathrm{OMe}, \mathrm{Me}, \mathrm{NO}_{2}, \mathrm{CN}$, etc; $\mathrm{R}_{2}=\mathrm{H}$,

*Address for Correspondence: Varala Ravi, Scrips Pharma, Mallapur, Hyderabad-500 076, Telangana, India, Tel: + 919618286529; E-mail: ravivarala@gmail.com

Copyright: $\odot 2020$ Parshuram MP, et al. This is an open-access article distributed under the terms of the creative commons attribution license which permits unrestricted use, distribution and reproduction in any medium, provided the original author and source are credited.

Received: 16 March, 2020; Accepted: 27 April, 2020; Published: 04 May, 2020 


\section{Reaction conditions}

2-aminobenzophenone $(1 \mathrm{mmol})$, benzaldehyde $(1 \mathrm{mmol})$, ammonium acetate $(2.5 \mathrm{mmol})$ was kept under visible light (using an LED bulb ( $\lambda \max =450 \mathrm{~nm}$ ) for the appropriate time.

\section{Experimental Section}

In a $25 \mathrm{~mL}$ round-bottom flask, the mixture of 2-aminobenzophenone (1 $\mathrm{mmol})$, benzaldehyde $(1 \mathrm{mmol})$, ammonium acetate $(2.5 \mathrm{mmol})$ was placed under irradiation using an LED bulb ( $\lambda$ max=450 nm) as the light source for the appropriate time shown in Table 1 . The progress of reaction was monitored by TLC (PET ether: ethylacetate 8:2). After completion of reaction, the reaction mixture was cooled at room temperature and crude product was recrystallized by ethyl alcohol.

\section{Spectral data of representative compounds}

2, 4-diphenylquinazoline (4a):Yellow solid, m. p:117- $119^{0} \mathrm{C}$; IR (KBr, $\left.\mathrm{cm}^{-1}\right)$ : 3410, 1622, 1534, 1445; ${ }^{1} \mathrm{H}$ NMR: $\left(400 \mathrm{MHz}, \mathrm{CDCl}_{3}\right): \delta=7.62-7.45(\mathrm{~m}$, $7 \mathrm{H}), 7.88-7.83(\mathrm{~m}, 3 \mathrm{H}), 8.12-8.15(\mathrm{~m}, 2 \mathrm{H}), 8.69(\mathrm{~m}, 2 \mathrm{H}){ }^{13} \mathrm{CNMR}$ : $400 \mathrm{MHz}$, $\mathrm{CDCl}_{3}$ ): $\delta=121.7,126.9,127.7,127.9,129.9,132.2,131.3,134.4,136.7$, 138.1, 153.2, 160.0, 168.1, MS: $\mathrm{m} / \mathrm{z}=283$.

2- (4- nitrophenyl)-4-phenylquinazoline (4b):White solid; m. p: $209^{0} \mathrm{C}$; IR $\left(\mathrm{KBr}, \mathrm{cm}^{-1}\right)$ : 3440, 1609, 1542, 1524, 1339, 837, 772, 706; ${ }^{1} \mathrm{H}$ NMR (400 $\left.\mathrm{MHz}, \mathrm{CDCl}_{3}\right): \delta=6.59(\mathrm{t}, \mathrm{J}=4.27 \mathrm{~Hz}, 4 \mathrm{H}), 7.20-7.30(\mathrm{~m}, 3 \mathrm{H}), 7.41(\mathrm{t}, \mathrm{J}=$ $6.6 \mathrm{~Hz}, 2 \mathrm{H}), 7.78(\mathrm{~d}, \mathrm{~J}=8.3 \mathrm{~Hz}, 2 \mathrm{H}), 8.37(\mathrm{~d}, \mathrm{~J}=8.3,2 \mathrm{H}) ;{ }^{13} \mathrm{C}$ NMR $(400$
$\left.\mathrm{MHz}, \mathrm{CDCl}_{3}\right): \delta=72,78,115,117,118,123.1,130.9,131.2,131.9,134.5$, 139.2, 147.3, 148.1, 150.0, 167.1; MS: $\mathrm{m} / \mathrm{z}=330$.

2- (2-Nitrophenyl-4-phenylquinazoline (4c):Brown solid; m. p: $127^{\circ} \mathrm{C}$; IR $\left(\mathrm{KBr}, \mathrm{cm}^{-1}\right): 3481,1614,1561,1524,1347,862,787,713 ;{ }^{1} \mathrm{H}$ NMR $(400 \mathrm{MHz}$, $\left.\mathrm{CDCl}_{3}\right): \delta=7.63-7.48(\mathrm{~m}, 7 \mathrm{H}), 7.83-7.74(\mathrm{~m}, 2 \mathrm{H}), 8.14-8.06(\mathrm{~m}, 4 \mathrm{H}) ;{ }^{13} \mathrm{C}$ NMR $\left(400 \mathrm{MHz}, \mathrm{CDCl}_{3}\right): \delta=118.3,121.5,121.8,122.2,124.1,127.2$, 128.1, 128.6, 128.9, 129.5, 130.1, 130.2, 132.1, 137.8, 149.1, 149.7, 161.6; $\mathrm{MS}: \mathrm{m} / \mathrm{z}=328$.

2- (4-chlorophenyl)-4- phenylquinazoline (4e):Yellow solid, m. p: $186^{\circ} \mathrm{C}$; IR $\left(\mathrm{KBr}, \mathrm{cm}^{-1}\right)$ : 3476, 2918, 2189, 1647, 1577, 874; ${ }^{1} \mathrm{H}$ NMR $(400 \mathrm{MHz}$, $\left.\mathrm{CDCl}_{3}\right): \delta=6.65-6.86(\mathrm{~m}, 5 \mathrm{H}), 7.16-7.91(\mathrm{~m}, 4 \mathrm{H}), 7.5(\mathrm{~d}, \mathrm{~J}=9.6 \mathrm{~Hz}, 2 \mathrm{H})$, $7.68(\mathrm{~d}, \mathrm{~J}=8.1 \mathrm{~Hz}, 2 \mathrm{H}) ;{ }^{13} \mathrm{C}$ NMR $\left(400 \mathrm{MHz}, \mathrm{CDCl}_{3}\right): \delta=70,77.1,77.6$, $77.9,113,117.2,117.6,127.2,127.8,127.9,131.2,132.5,138.12,141.23$, 147.11, 166.3; MS: $\mathrm{m} / \mathrm{z}=319$.

4-phenyl-2-p-tolyquinazoline (4)):White solid; m. p:166-168 ${ }^{\circ} \mathrm{C}$; IR $(\mathrm{KBr}$, $\left.\mathrm{cm}^{-1}\right): 3312,1609,1569,1533,1339,1070,771,697 ;{ }^{1} \mathrm{H}$ NMR $(400 \mathrm{MHz}$, $\left.\mathrm{CDCl}_{3}\right): \delta=2.45(\mathrm{~s}, 3 \mathrm{H}), 7.30(\mathrm{~d}, \mathrm{~J}=7.7 \mathrm{~Hz}, 2 \mathrm{H}), 7.69-7.47(\mathrm{~m}, 4 \mathrm{H}), 7.78$ - $7.65(\mathrm{~m}, 3 \mathrm{H}), 8.11(\mathrm{t}, \mathrm{J}=7.55,2 \mathrm{H}), 8.53(\mathrm{~d}, \mathrm{~J}=8.1 \mathrm{~Hz}, 2 \mathrm{H}) ;{ }^{13} \mathrm{C}$ NMR $(400$ $\left.\mathrm{MHz}, \mathrm{CDCl}_{3}\right): \delta=21.6,121.3,125.1,125.52,126.8,126.9,126.9,127.4$, $128.2,129.3,132.8,133.2,139.2,143.7,151.2,158.6 ; \mathrm{MS}: \mathrm{m} / \mathrm{z}=297$.

\section{Results and Discussion}

Table 1 shows both the electron-withdrawing and electron donating groups are unaffected on the reaction time and yield of products.

Table 1. Synthesis of quinazoline derivatives by using various benzaldehydes.

\begin{tabular}{|c|c|c|c|c|}
\hline S. No & Aldehyde & Product & Time (min) & Yield $^{a, b}$ \\
\hline 1 & Benzaldehyde & $4 a$ & 45 & 86 \\
\hline 2 & 4-Nitro benzaldehyde & $4 b$ & 51 & 90 \\
\hline 3 & 2-Nitro benzaldehyde & $4 c$ & 57 & 79 \\
\hline 4 & 3-Nitro benzaldehyde & $4 d$ & 49 & 87 \\
\hline 5 & 4-Chloro benzaldehyde & $4 e$ & 40 & 94 \\
\hline 6 & 3-Chloro benzaldehyde & $4 f$ & 46 & 90 \\
\hline 7 & 4-Fluoro benzaldehyde & $4 g$ & 54 & 91 \\
\hline 8 & 4-Bromo benzaldehyde & $4 \mathrm{~h}$ & 41 & 92 \\
\hline 9 & 4-Methoxy benzaldehyde & $4 i$ & 40 & 95 \\
\hline 10 & 4-Methyl benzaldehyde & $4 j$ & 38 & 94 \\
\hline 11 & 3, 4-Dimethoxy benzaldehyde & $4 \mathrm{k}$ & 45 & 86 \\
\hline 12 & 2-Hydroxy benzaldehyde & 41 & 57 & 90 \\
\hline 13 & 3- Hydroxy benzaldehyde & $4 m$ & 50 & 82 \\
\hline 14 & 4-Hydroxy benzaldehyde & $4 n$ & 45 & 85 \\
\hline 15 & 4-Cyano benzaldehyde & 40 & 40 & 89 \\
\hline
\end{tabular}

${ }^{\mathrm{a}}$ s solated yield and ${ }^{\mathrm{b}}$ Products are characterized by IR, ${ }^{1} \mathrm{H}$ NMR 
Initially, we chose 2-aminobenzophenone ( $1 \mathrm{mmol})$, benzaldehyde (1 $\mathrm{mmol})$, ammonium acetate $(2.5 \mathrm{mmol})$, as model reaction to assess the solvent efficacy. Variety of organic solvents such as DMSO, MeCN, MeOH, $\mathrm{CH} 2 \mathrm{Cl} 2$, EtOAc and toluene were examined. There is no product formation in toluene. When the reaction was performed in $\mathrm{MeCN}, \mathrm{MeOH}$ it resulted in trace amounts of product and large amount side product formation. In solvents like $\mathrm{CH} 2 \mathrm{Cl} 2$, EtOAc and DMSO, lower yield of product was obtained.
So, we performed reaction in solvent-free condition and best result in terms of time and yield was observed.

Our methodology is mild and effective with clean and renewable energy source. The further scope of the substrate was expanded with a variety of aldehydes.

Comparative studies of different reaction conditions, confirm the efficacy of present methodology (Entry 8, Table 2).

Table 2. Comparative studies of catalyst with present methods.

\begin{tabular}{llllll} 
Entry & Catalyst & Loading & Reaction Conditions & Time(h/min) & Solvent \\
\hline 1 & $\mathrm{Bu}_{3} \mathrm{SnH} /$ Triethyl Borane & $0.76 / 3.6$ equiv. & inert & $10 /$ & dry toluene \\
\hline 2 & $\mathrm{Nil}$ & - & $300 \mathrm{~W} \mathrm{~h}$ at $150^{\circ} \mathrm{C}$ & $10 /$ & Solvent-free \\
\hline 3 & $\mathrm{Zn}(\mathrm{OTf})_{2}$ & $5 \mathrm{~mol}$ & reflux & $6-12 /$ & toluene \\
\hline 4 & Molecular iodine & $10 \mathrm{~mol}$ & $40^{\circ} \mathrm{C}$ & $2.5 /$ & Heat or ethanol \\
\hline 5 & $\mathrm{CsOH}$ & $0.5 \mathrm{mmol}$ & $60^{\circ} \mathrm{C}$ & $24 /$ & acetonitrile \\
\hline 6 & $\mathrm{NaOH}$ & $2 \mathrm{~mol}$ & Hg Lamp $335 \mathrm{~nm}$ & $2-5.5 /$ & acetonitrile \\
\hline 7 & $\mathrm{HCOONH}_{4}, \mathrm{PhCOCl}_{2} \mathrm{Et} \mathrm{N}_{3}$ & 20 equiv. & Microwave, high pressure & $14-20$ & Nil
\end{tabular}

\section{Conclusion}

We have developed highly efficient method for the synthesis of quinazoline derivatives via visible light mediated $\mathrm{C}-\mathrm{H}$ activation. The advantages of the present method are use of eco-friendly conditions, easily available starting materials; high yields, short reaction time and less energy consume process.

\section{Acknowledgements}

Dr. Ravi Varala thanks Dr. Ch. V. Rajasekhar for his kind support and encouragement.

\section{References}

1. Bergman, Robert G. "C-H activation." Nature 446 (2007): 391-393.

2. Godula, Kamil, and Dalibor Sames. "CH bond functionalization in complex organic synthesis." Science 312 (2006): 67-72.

3. Lewis, Nathan S. "Toward cost-effective solar energy use." science 315 (2007): 798-801.

4. Paul, A, and D. Chatterjee. "Rajkamal; Halder, T.; Banerjee, S, Yadav, S." Tetrahedron Lett 56 (2015): 2496-2499

5. Kumar, Atul, Garima Gupta, and Suman Srivastava. "Functional ionic liquid mediated synthesis (FILMS) of dihydrothiophenes and tacrine derivatives." Green Chemistry 13 (2011): 2459-2463.

6. Xie, Jin, Hongming Jin, Pan $\mathrm{Xu}$, and Chengjian Zhu. "When $\mathrm{C}-\mathrm{H}$ bond functionalization meets visible-light photoredox catalysis." Tetrahedron Letters 55 (2014): 36-48.

7. Ahuja, Sapna, Ramya Raghunathan, Elango Kumarasamy, Steffen Jockusch, and Jayaraman Sivaguru. "Realizing the Photoene Reaction with Alkenes under Visible Light Irradiation and Bypassing the Favored [2+2]-
Photocycloaddition." Journal of the American Chemical Society 140 (2018): 13185-13189.

8. Chen, Li, Yohei Kametani, Kenji Imamura, Tsukasa Abe, Yoshihito Shiota, Kazunari Yoshizawa, Yoshio Hisaeda, and Hisashi Shimakoshi. "Visible lightdriven cross-coupling reactions of alkyl halides with phenylacetylene derivatives for C (sp 3)-C (sp) bond formation catalyzed by a B 12 complex." Chemical Communications 55 (2019): 13070-13073.

9. Uygur, Mustafa, and Olga García Mancheño. "Visible light-mediated organophotocatalyzed $\mathrm{C}-\mathrm{H}$ bond functionalization reactions." Organic $\mathcal{E}$ Biomolecular Chemistry 17 (2019):5475-5489.

10. Narayanam, Jagan MR, and Corey RJ Stephenson. "Visible light photoredox catalysis: applications in organic synthesis." Chemical Society Reviews 40 (2011): 102-113.

11. Shi, Lei, and Wujiong Xia. "Photoredox functionalization of $\mathrm{C}-\mathrm{H}$ bonds adjacent to a nitrogen atom." Chemical Society Reviews 41 (2012): 7687-7697.

12. Xuan, Jun, and Wen - Jing Xiao. "Visible - light photoredox catalysis." Angewandte Chemie International Edition 51 (2012): 6828-6838.

13. Yoon, Tehshik P., Michael A. Ischay, and Juana Du. "Visible light photocatalysis as a greener approach to photochemical synthesis." Nature chemistry 2 (2010): 527-529.

14. Teplý, Filip. "Photoredox catalysis by [Ru (bpy) 3] 2+ to trigger transformations of organic molecules. Organic synthesis using visible-light photocatalysis and its 20th century roots." Collection of Czechoslovak Chemical Communications 76 (2011): 859-917.

15. Xi, Yumeng, Hong Yi, and Aiwen Lei. "Synthetic applications of photoredox catalysis with visible light." Organic \& Biomolecular Chemistry 11 (2013): 2387-2403.

16. Sheldon, Roger A. "Green solvents for sustainable organic synthesis: state of the art." Green Chemistry 7 (2005): 267-278.

17. Yoshida, Shigemi, et al. "Production of 2-methyl-4 [3H]-quinazolinone, an inhibitor of poly (ADP-ribose) synthetase, by bacterium." The Journal of Antibiotics 44 (1991): 111-112. 
18. Malamas, Michael S, and Jane Millen. "Quinazolineacetic acids and related analogs as aldose reductase inhibitors." Journal of Medicinal Chemistry 34 (1991): 1492-1503.

19. Hess, Hans J, Timothy H. Cronin, and Alexander Scriabine. "Antihypertensive 2-amino-4 (3H)-quinazolinones." Journal of Medicinal Chemistry 11 (1968): 130-136.

20. Doyle, L. Austin, and Douglas D. Ross. "Multidrug resistance mediated by the breast cancer resistance protein BCRP (ABCG2)." Oncogene 22 (2003): 7340-7358.

21. Henderson, Elisa A., Vassilios Bavetsias, Davinder S. Theti, Stuart C. Wilson, Rainer Clauss, and Ann L. Jackman. "Targeting the a -folate receptor with cyclopenta [g] quinazoline-based inhibitors of thymidylate synthase." Bioorganic \& Medicinal Chemistry 14 (2006): 5020-5042.

22. Takahashi, Takashi, Hiroshi Tanaka, Akihisa Matsuda, Takayuki Doi, and Haruo Yamada. "Synthesis of 9-membered masked enediyne analogues possessing DNA intercalator and sugar moieties." Bioorg. Med. Chem. Lett 8 (1998): 3287-3291.

23. Waisser, Karel, Jiři Gregor, Hynek Dostál, Jiøi Kuneš, Lenka Kubicová, Věra Klimešová, and Jarmila Kaustová."Influence of the replacement of the oxo function with the thioxo group on the antimycobacterial activity of 3-aryl-6, 8dichloro-2H-1, 3-benzoxazine-2, 4 (3H)-diones and 3-arylquinazoline-2, 4 (1H, 3H)-diones." // Farmaco 56 (2001): 803-807.

24. Grover, Gaurav, and Suvarna G. Kini. "Synthesis and evaluation of new quinazolone derivatives of nalidixic acid as potential antibacterial and antifungal agents." European Journal of Medicinal Chemistry 41 (2006): 256-262.

25. Chao, Qi, Lynn Deng, Hsiencheng Shih, Lorenzo M. Leoni, Davide Genini, Dennis A. Carson, and Howard B. Cottam. "Substituted isoquinolines and quinazolines as potential antiinflammatory agents. Synthesis and biological evaluation of inhibitors of tumor necrosis factor a ." Journal of Medicinal Chemistry 42 (1999): 3860-3873

26. Chien, Tun-Cheng, Chien-Shu Chen, Fang-Hwa Yu, J. W. Chern, and Nucleosides XI. "Synthesis and Antiviral Evaluation of 5'-Alkylthio-5'-deoxy Quinazolinone Nucleoside Derivatives as S-Adenosyl-L-homocysteine Analogs." Chem. Pharm. Bul/52 (2004): 1422-1426.

27. Herget, Thomas, Martina Freitag, Monika Morbitzer, Regina Kupfer, Thomas Stamminger, and Manfred Marschall. "Novel chemical class of pUL97 protein kinase-specific inhibitors with strong anticytomegaloviral activity." Antimicrobial Agents and Chemotherapy 48 (2004): 4154-4162.

28. Plé, Patrick A., Tim P. Green, Laurent F. Hennequin, Jon Curwen, Michael Fennell, Jack Allen, Christine Lambert-van der Brempt, and Gerard Costello."Discovery of a new class of anilinoquinazoline inhibitors with high affinity and specificity for the tyrosine kinase domain of c-Src." Journal of Medicinal Chemistry 47 (2004): 871-887.

29. Seo, Han Na, Ja Youn Choi, Yun Jeong Choe, Yoonjee Kim, Hyewhon Rhim, So Ha Lee, Jungahn Kim, Dong Jun Joo, and Jae Yeol Lee.. "Discovery of potent T-type calcium channel blocker." Bioorganic \& Medicinal Chemistry Letters 17 (2007): 5740-5743.

30. Colotta, Vittoria, Daniela Catarzi, Flavia Varano, Ombretta Lenzi, Guido Filacchioni, Chiara Costagli, Alessandro Galli et al. "Structural investigation of the 7-chloro-3-hydroxy-1 H-quinazoline-2, 4-dione scaffold to obtain AMPA and kainate receptor selective antagonists. synthesis, pharmacological, and molecular modeling studies." Journal of Medicinal Chemistry 20 (2006): 6015-6026

31. Bowman, W. Russell, Mark RJ Elsegood, Tobias Stein, and George W. Weaver."Radical reactions with $3 \mathrm{H}$-quinazolin-4-ones: synthesis of deoxyvasicinone, mackinazolinone, luotonin $A$, rutaecarpine and tryptanthrin." Organic \& Biomolecular Chemistry 5 (2007): 103-113.

32. Sarma, Rupam, and Dipak Prajapati. "Microwave-promoted efficient synthesis of dihydroquinazolines." Green Chemistry 13 (2011): 718-722.

33. Ye, L., Yu L, Zhu L, and Xia X. "One-pot tandem synthesis of 2arylquinazolines by a multicomponent cyclization reaction." Molecules 18 (2013): 13860-13869.

34. Madabhushi, Sridhar. "One-step method for synthesis of 2, 4-disubstituted quinazoline 3-oxides by reaction of a 2-aminoaryl ketone with a hydroxamic acid using Zn (OTf) 2 as the catalyst." Tetrahedron Letters 55.12 (2014): 1979-1982.

35. Racles, Carmen, Mirela-Fernanda Zaltariov, Mihail lacob, Mihaela Silion, Mihaela Avadanei, and Alexandra Bargan. "Siloxane-based metal-organic frameworks with remarkable catalytic activity in mild environmenta photodegradation of azo dyes." Applied Catalysis B: Environmental 205 (2017): 78-92

36. Bandaru, Madhav. "Simple and straight forward synthesis of 2, 4disubstituted quinazolines in aqueous medium." European Journal of Chemistry 3 (2012): 252-257.

37. Panja, Sumit Kumar, Nidhi Dwivedi, and Satyen Saha. "I2-Catalyzed threecomponent protocol for the synthesis of quinazolines." Tetrahedron Letters 53 (2012): 6167-6172.

How to cite this article: Parshuram MP, Vinod TK, Ravi V and Pradip BG. "Visible Light Promoted One-Pot, Three Component Reaction for the Synthesis of quinazolines". Chem Sci J 11 (2020) doi: 10.37421/csj.2020.11.206 